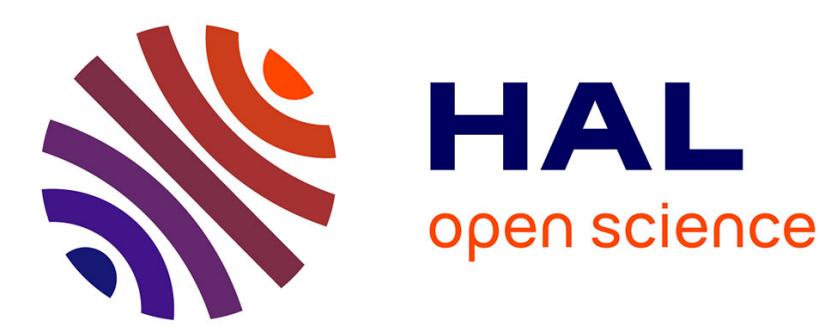

\title{
Meteoric fluid-rock interaction in Variscan shear zones
}

Camille Dusséaux, Aude Gébelin, Philippe Boulvais, Véronique Gardien,

Stephen Grimes, Andreas Mulch

\section{To cite this version:}

Camille Dusséaux, Aude Gébelin, Philippe Boulvais, Véronique Gardien, Stephen Grimes, et al.. Meteoric fluid-rock interaction in Variscan shear zones. Terra Nova, 2019, 31 (4), pp.366-372. $10.1111 /$ ter.12392 . insu-02270566

\section{HAL Id: insu-02270566 https://hal-insu.archives-ouvertes.fr/insu-02270566}

Submitted on 7 Aug 2020

HAL is a multi-disciplinary open access archive for the deposit and dissemination of scientific research documents, whether they are published or not. The documents may come from teaching and research institutions in France or abroad, or from public or private research centers.
L'archive ouverte pluridisciplinaire HAL, est destinée au dépôt et à la diffusion de documents scientifiques de niveau recherche, publiés ou non, émanant des établissements d'enseignement et de recherche français ou étrangers, des laboratoires publics ou privés. 
2019-04-09

\title{
Meteoric fluidrock interaction in Variscan shear zones
}

\author{
Dusseaux, C
}

http://hdl.handle.net/10026.1/14383

10.1111/ter.12392

Terra Nova

Wiley

All content in PEARL is protected by copyright law. Author manuscripts are made available in accordance with publisher policies. Please cite only the published version using the details provided on the item record or document. In the absence of an open licence (e.g. Creative Commons), permissions for further reuse of content should be sought from the publisher or author. 
MS CAMILLE DUSSÉAUX (Orcid ID : 0000-0002-4716-5414)

Article type : Paper

Received date: $19-$ Nov-2018

Revised version received date: 03-Mar-2019

Accepted date: 27-Mar-2019

Correspondence details:

Ms Camille Dusséaux

School of Geography, Earth and Environmental Sciences,

University of Plymouth Room

406 Fitzroy building

Plymouth

Devon PL4 8AA

UK

E-mail: camille,dusseaux@plymouth.ac.uk

\title{
Meteoric fluid-rock interaction in Variscan shear zones
}

\section{Camille Dusséaux ${ }^{1}$, Aude Gébelin ${ }^{1}$, Philippe Boulvais ${ }^{2}$, Véronique Gardien ${ }^{3}$, Stephen \\ Grimes $^{1}$ and Andreas Mulch ${ }^{4,5}$}

${ }^{I}$ School of Geography, Earth and Environmental Sciences, University of Plymouth, PL48AA Plymouth, UK

${ }^{2}$ Géosciences Rennes UMR 6118, OSUR, Université Rennes 1, 35042 Rennes, France

${ }^{3}$ Laboratoire de Géologie de Lyon, Université Lyon 1, 69622 Villeurbanne, France

${ }^{4}$ Senckenberg Biodiversity and Climate Research Centre, 60325 Frankfurt, Germany

${ }^{5}$ Institute of Geosciences, Goethe University Frankfurt, 60438 Frankfurt, Germany

\begin{abstract}
Variscan shear zones in the Armorican Massif represent sites of strong fluid-rock interaction. The hydrogen isotope composition of muscovite $\left(\delta \mathrm{D}_{\mathrm{Ms}}\right)$ from syntectonic leucogranite allows to determine the source of fluids that infiltrated the footwall of three detachment zones and the South Armorican Shear Zone. Using temperatures of hydrogen isotope exchange estimated from microstructural data, we calculate the hydrogen isotope ratios of water

This article has been accepted for publication and undergone full peer review but has not been through the copyediting, typesetting, pagination and proofreading process, which may lead to differences between this version and the Version of Record. Please cite this article as doi: $10.1111 /$ ter.12392

This article is protected by copyright. All rights reserved.
\end{abstract}


$\left(\delta \mathrm{D}_{\text {water }}\right.$ ) present within the shear zones during high temperature deformation. $\mathrm{A} \sim 40 \%$ difference in $\delta \mathrm{D}_{\text {water }}$ values from deep to shallow crustal level reveals a mixing relationship between deep crustal fluids with higher $\delta \mathrm{D}$ values that range from -34 to $-33 \%$, and meteoric fluids with $\delta \mathrm{D}$ values as low as $-74 \%$ in the upper part of detachment footwalls.

\section{Introduction}

Crustal-scale shear zones are sites of significant fluid circulation and hydrothermal alteration (e.g. McCaig, 1988; Fricke et al., 1992; Mulch et al., 2006b; Gébelin et al., 2011; Menzies et al., 2014). They represent critical interfaces where metamorphic, magmatic and surfacederived fluids meet (e.g. Upton et al., 1995; Nesbitt and Muehlenbachs, 1995; Mulch et al., 2006b; Gébelin et al., 2015, 2017). Characterization of a meteoric component of crustal fluids is crucial to better understand ore deposition at the orogen scale (e.g. Boiron et al., 2003) or for paleoaltimetry reconstructions (e.g. Mulch et al., 2004, 2007; Gébelin et al., 2012, 2013). Muscovite that crystallized at depth during deformation-related fluid flow provides a reliable record to track meteoric-derived fluids that circulated in ductile shear zones during high temperature deformation ( $400-600^{\circ} \mathrm{C}$; e.g. Gébelin et al., 2011, 2015; Methner et al., 2015). In particular, the hydrogen isotope ratio of the fluid $\left(\delta \mathrm{D}_{\text {water }}\right)$ can be estimated if muscovitewater hydrogen isotope equilibrium was attained during deformation and crystallization, and if the temperature of isotope exchange can be assessed independently (Fricke et al., 1992; Mulch and Cosca, 2004; Mulch et al., 2007). In addition, the high resistance of muscovite to post-deformational alteration and low-temperature isotopic exchange makes it an excellent tracer of water present during deformation (e.g. Guggenheim et al., 1987; Mariani et al., 2006).

This method has proven to be one of the cornerstones when recovering the isotopic composition of ancient rainfall that infiltrated the upper crust through a brittle deformation network down to $15 \mathrm{~km}$ depth in the footwall of detachment zones in the North American Cordillera (e.g. Fricke et al., 1992; Losh, 1997; Mulch et al., 2004, 2007; Gébelin et al., 2011, 2012, 2015), in the European Central Alps (Campani et al., 2012) but also in the Himalaya (Gébelin et al., 2013, 2017).

Here, we employ hydrogen isotope geochemistry of synkinematic muscovite $\left(\delta \mathrm{D}_{\mathrm{Ms}}\right)$ from Variscan strike-slip and detachment footwalls of the Armorican Massif (Fig. 1) to identify and characterize ancient meteoric water that circulated along and across the brittle-ductile transition. Low $\delta \mathrm{DMs}$ values indicate that meteoric fluids infiltrated the upper part of detachments footwall and strike-slip shear zones to variable degrees.

This article is protected by copyright. All rights reserved. 


\section{Geological framework}

The southern Armorican domain represents the internal zone of the Variscan Belt that experienced crustal thickening and high-pressure metamorphism during the Carboniferous (e.g. Ballèvre et al., 2013). From top to bottom, three units can be distinguished (Fig. 1): 1) Upper units (blueschists and greenschist facies metasediments and metavolcanics; Bosse et al., 2002; Le Hébel et al., 2002); 2) Intermediate units (mica schist; Barrovian metamorphism from greenschist to amphibolite facies conditions; Triboulet and Audren, 1988); 3) Lower units (migmatites; $750^{\circ} \mathrm{C}-1000 \mathrm{MPa}$; Jones and Brown (1990) and syntectonic peraluminous leucogranites).

The entire region was affected by coeval WNW-ESE trending dextral strike-slip and E-W extensional faulting during the late-Carboniferous that provided effective pathways for melt migration and fluid infiltration (e.g. Gapais et al., 2015). Syntectonic two-mica leucogranites forming the footwall of detachment shear zones and spatially associated with the dextral South Armorican Shear Zone (SASZ) were emplaced between 320 and $300 \mathrm{Ma}$ (Ar/Ar on muscovite and U-Th-Pb on zircon and monazite; e.g. Jegouzo, 1980; Gapais, 1989; Brown and Dallmeyer, 1996; Turrillot et al., 2009, 2011a; Tartèse et al., 2012; Ballouard et al., 2015, 2017; Gapais et al., 2015).

\section{Sampling strategy and sample description}

To characterize the role of different types of active shear zones in controlling meteoric water infiltration in the Variscan crust, oriented samples of highly to weakly deformed leucogranites were collected along the SASZ and following transects from Quiberon and Piriac detachment shear zones into their underlying mylonitic footwalls (samples locations in the Supporting Information). Some leucogranites display albitic and chloritic alteration that, together with the presence of quartz veins, point to the involvement of magmatic and/or hydrothermal fluids (higher $\mathrm{Sn}$ and $\mathrm{Cs}$ content and lower $\mathrm{K} / \mathrm{Rb}$ and $\mathrm{Nb} / \mathrm{Ta}$ ratios; e.g. Ballouard et al., 2016). Also, the involvement of surface-derived fluids is suspected by oxygen isotope analysis $\left(\delta^{18} \mathrm{O}_{\mathrm{Quartz}}\right.$ values as low as $-2 \%$ in quartz veins formed at $\sim 250$ $350^{\circ}$ C; e.g. Lemarchand et al., 2012; Tartèse et al., 2012; Ballouard et al., 2017). We also collected leucogranite samples from the Sarzeau detachment shear zone that allows the observation of a deeper structural level (e.g. Gapais et al., 2015).

Sub-solidus deformation textures such as rectangular and castellate quartz grain boundaries indicate that grain boundary migration $\left(\geq 550^{\circ} \mathrm{C}\right.$; e.g. Stipp et al., 2002 ; Bukovská et al., 2016) was the dominant dynamic recrystallization process that affected mylonitic syntectonic 
leucogranites from all three types of shear zones (Fig. 2). These microstructural observations, together with EBSD data indicating prism $<\mathrm{c}>$ and $<\mathrm{a}>$ glide (Gapais and Boundi, 2014; Bukovská et al., 2016), support high deformation temperature $\left(\geq 400^{\circ} \mathrm{C}\right.$, e.g. Langille et al., 2010).

C-S structures highlighted by muscovite fish along shear and schistosity planes indicate a syntectonic emplacement of leucogranites (e.g. Gapais, 1989; Fig. S1A, Supporting Information). Solution-precipitation mechanisms can explain the development of synkinematic lozenge-shaped muscovite grains (groups 1, 2 and 3 of ten Grotenhuis et al. (2003) classification; Figs. S1 and S2). Weakly deformed granite display euhedral muscovite grains and large primary quartz crystals and/or quartz grain boundary migration consistent with high-temperature deformation (Fig. S2).

\section{Hydrogen Isotope Geochemistry}

$\delta \mathrm{D}$ values of muscovite $\left(\delta \mathrm{D}_{\mathrm{Ms}}\right)$ were measured in 51 syntectonic leucogranite samples from the different ductile shear zones (Fig. 2; Text $\mathrm{S} 1$ and Table $\mathrm{S} 1$ ). $\delta \mathrm{D}_{\mathrm{Ms}}$ values from the Sarzeau detachment footwall (SARZ-) range from -47 to $-46 \%$. $\delta D_{\mathrm{Ms}}$ values from the Quiberon (QUIB-) and Piriac (PIR-, GUE-) transects are constant within the footwall from the top to the bottom and range from -88 to $-76 \%$. Weakly deformed leucogranites located at larger distance from the hanging wall (GUEweakd-) have similar values (-84 to $-80 \%$ ). $\delta \mathrm{D}_{\mathrm{Ms}}$ values from mylonitic samples from the SASZ (ELL-, QRT-, QUEST-, LRT-) vary from -84 to $-54 \%$. The range of values allows to define a lateral trend from lower $\delta \mathrm{D}_{\mathrm{Ms}}$ values (-84 to $-79 \%$ ) obtained on highly deformed samples within the SASZ to higher $\delta D_{M s}$ values (-79 and $-70 \%$ ) at increasing distance from the deformation zone where leucogranites are weakly deformed (GRTweakd-, LRTweakd-; Figs. 1 and 2).

Based on our microstructural observations (e.g. C-S structures and quartz Grain Boundary Migration; $\geq 550^{\circ} \mathrm{C}$; e.g. Stipp et al., 2002) and previous EBSD data $\left(\geq 400^{\circ} \mathrm{C}\right.$; Gapais and Boundi, 2014; Bukovská et al., 2016), we used a temperature of deformation of $550 \pm 100^{\circ} \mathrm{C}$ which corresponds to the temperature of hydrogen isotope exchange between the fluid and the mineral. Together with measured $\delta \mathrm{D}_{\mathrm{Ms}}$ values and using the hydrogen isotope muscovitewater fractionation of Suzuoki and Epstein (1976), $\delta \mathrm{D}$ values of the fluid $\left(\delta \mathrm{D}_{\text {water }} \pm 10 \%\right.$ o taking into account analytical and temperature uncertainties) present during deformation and (re)crystallization were calculated and vary from -34 to $-33 \%$ in the Sarzeau detachment zone, from -74 to $-63 \%$ in the Quiberon and Piriac detachment zones, and from -71 to $-41 \%$ in the SASZ (Figs. 1, 2 and 3; Table S2).

This article is protected by copyright. All rights reserved. 


\section{Discussion}

\section{Meteoric infiltration and mixing with deep crustal fluids}

Samples from Sarzeau exposing the deepest part of a detachment footwall display calculated $\delta \mathrm{D}_{\text {water }}$ values of -34 to $-33 \%$ which are significantly higher than those obtained from the Quiberon and Piriac detachments $\left(\delta \mathrm{D}_{\text {water }}\right.$ values as low as $-74 \%$; Fig. 3$)$. $\delta \mathrm{D}_{\text {water }}$ values calculated from samples collected in the SASZ vary from -71 to $-41 \%$, covering the entire range of hydrogen isotope compositions found in Sarzeau and in Quiberon and Piriac. Considering that the Sarzeau granite was emplaced at $\sim 15 \mathrm{~km}$ depth (Turrillot et al., 2011b), we interpret the highest calculated $\delta \mathrm{D}_{\text {water }}$ value ( -33\%) to reflect the hydrogen isotope composition of a deep crustal fluid $\left(-70 \%_{0}<\delta \mathrm{D}_{\text {metamorphic fluids }}<-20 \%\right.$ and/or $-80 \%$ o $<$ $\delta \mathrm{D}_{\text {magmatic fluids }}<-40 \%$; e.g. Field and Fifarek, 1985) present during deformation at such a depth. In contrast, the lower $\delta \mathrm{D}_{\text {water }}$ values obtained from Quiberon and Piriac (-74\%o to $-63 \%$ ) suggest that muscovite from these syntectonic leucogranites interacted with deuterium-depleted fluids during deformation. These lower $\delta \mathrm{D}_{\text {water }}$ values $(41 \%$ lower than those obtained from Sarzeau) can most readily be explained by the involvement of meteoric fluids, in good agreement with the shallower depths of granite emplacement at Quiberon and Piriac ( 3-6 km; Le Hébel et al., 2007; Ballouard et al., 2017).

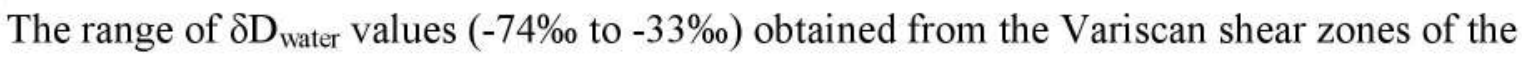
southern Armorican domain indicates a mixing relationship between deep crustal fluids and meteoric fluids in the mylonitic detachment footwalls and along the SASZ. As shown in Figs. 3 and 4, we define two fluid end-members: a crustal fluid that predominantly involves magmatic and/or metamorphic fluids $\left(\delta \mathrm{D}_{\text {water }}\right.$ value $=-33 \%$ ) and a surface-derived fluid that reflects a large percentage of mixing with low- $\delta \mathrm{D}$ meteoric water $\left(\delta \mathrm{D}_{\text {water }}\right.$ value $=-74 \%$ ) The variability in the low $\delta \mathrm{D}_{\text {water }}$ values within the Quiberon and Piriac detachment zones $(-74$ to $-63 \%)$ and in the SASZ ( -71 to $-41 \%$ ) can be explained by 1$)$ different degrees of mixing with meteoric water, and 2) a difference in the temperature controlling the hydrogen isotope exchange between the fluid and synkinematic muscovite $\left( \pm 100^{\circ} \mathrm{C}\right.$ gives an uncertainty of $\pm 10 \%$ for the $\delta \mathrm{D}_{\text {water }}$ values).

In addition, we suggest that the lowest $\delta \mathrm{D}_{\text {water value of }}-74 \%$ represents the hydrogen isotope composition which approximates most closely the value of surface-derived fluid that penetrated the crust at depth during detachments activity (Fig. 3). As the downward penetration of meteoric fluids in the crust generally leads to an increase in $\delta \mathrm{D}_{\text {water }}$ values due to fluid-rock interaction, this $\delta \mathrm{D}_{\text {water }}$ value represents a maximum value that may have been 
potentially lower than $-74 \%$ if it would have been extracted from the near-surface geological record (e.g. Gébelin et al., 2012).

\section{Timing, depth and mechanisms of meteoric fluid infiltration}

The onset of meteoric fluid infiltration can be estimated at $\sim 320 \mathrm{Ma}$ based on U/Pb ages from syntectonic leucogranites emplaced in detachment footwalls or along strike-slip shear zones (e.g. Tartèse et al., 2012; Ballouard et al., 2015). Deformation and fluid infiltration likely ended at $\sim 300 \mathrm{Ma}$ with the cessation of the shear zones activity $\left({ }^{40} \mathrm{Ar} /{ }^{39} \mathrm{Ar}\right.$ muscovite ages from the same studied leucogranite intrusion; Turrillot et al., 2011a; Tartèse et al., 2012; Gapais et al., 2015; Ballouard et al., 2017, 2018).

Based on the depth at which leucogranites were emplaced at Quiberon and Piriac ( $\sim 3$ to 6 $\mathrm{km}$ ) and along the SASZ ( $\sim 3$ to $12 \mathrm{~km})$, we estimate a minimum depth of $\sim 3 \mathrm{~km}$ for the infiltration of Carboniferous meteoric fluids. However, based on the depth of Sarzeau granite emplacement $(\sim 15 \mathrm{~km})$ and on its deep crustal fluid signature, we infer that the penetration of meteoric fluids in the crust did not exceed $\sim 12 \mathrm{~km}$ corresponding to the deepest level of leucogranites emplacement in the SASZ (e.g. Le Hébel et al., 2007; Tartèse and Boulvais, 2010; Turrillot et al., 2011b; Ballouard et al., 2017).

These results are in good agreement with previous studies conducted on ductile shear zones in the Pyrenees, the New Zealand Alps, the North American Cordillera and the Himalaya that highlight the infiltration of meteoric fluids at similar depths (e.g. McCaig, 1988; Upton et al., 1995; Mulch et al., 2004, 2006; Person et al., 2007; Gébelin et al., 2011, 2017; Menzies et al., 2014). As proposed for detachment zones in Western USA and the South Tibetan

Detachment (Mulch et al., 2004; Person et al., 2007, Gébelin et al., 2011, 2013; 2015, 2017), three main conditions are essential to explain the downward infiltration of meteoric fluids at depth and imply a combined effect of brittle normal faults in the upper crust, a high geothermal gradient and the presence of a hydraulic head. These criteria were very likely met in the southern Armorican domain where brittle normal faults have been recognized and linked to the exhumation of high-grade metamorphic rocks at $\sim 300 \mathrm{Ma}$, but also where the thickened crust would have provided the necessary hydraulic head (Fig. 3; e.g. Gapais et al., 2015; Brown and Dallmeyer, 1996).

Fault-valve could represent another mechanism for the downward flow of small volumes of meteoric fluids where quick episodes of fluid penetration are followed by protracted periods of fluid stagnation promoting fluid-rock interaction under lithostatic conditions (e.g. Sibson, 
1981; McCaig, 1988; Sibson et al., 1988; Jenkin et al., 1994; Upton et al., 1995; Menzies et al., 2014), in good agreement with our rock-buffered meteoric fluid signatures.

\section{Isotopic composition of ancient rainfall in the Armorican Massif}

Low- $\delta \mathrm{D}$ meteoric precipitation typical of high-altitude regions $\left(\delta \mathrm{D}_{\text {water }} \sim-150 \%\right.$ in the Himalayas; e.g. Quade et al., 2011) are expected in the thickened Armorican Massif. Although our data highlight the presence of meteoric fluids at depth, $\delta \mathrm{D}$ values of these surface waters (estimated at -74\%o) remain relatively high if corresponding to the initial meteoric water (see above). Four main factors can explain these relatively high $\delta \mathrm{D}$ values for Carboniferous rainfall: 1) a moderate paleoelevation as hydrogen $(\delta \mathrm{D})$ isotope ratios of rainfall scale with elevation on the windward side of a mountain range (e.g. Poage and Chamberlain, 2001); 2) the equatorial paleogeographic position of the Armorican Massif during the late-Carboniferous (e.g. Tait et al., 1996; Boucot et al., 2013) would have yielded higher $\delta \mathrm{D}_{\text {rainfall }}$ values as observed today due to the high global evaporation flux over the oceans at the equator (Rozanski et al., 1993); 3) the warm equatorial late-Carboniferous paleoclimate that characterized the Variscan belt of western Europe could lead to relatively

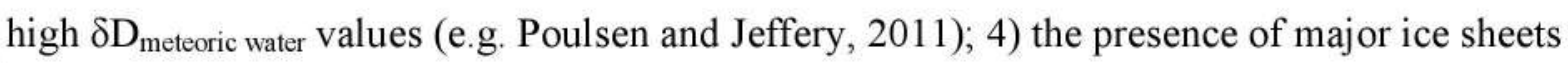
( $40 \%$ more extensive than today) during the late-Carboniferous may have induced an increase of $+1.5 \%$ in the $\delta^{18} \mathrm{O}$ of ocean waters or $+12 \%$ for the $\delta \mathrm{D}_{\text {ocean water values (González- }}$ Bonorino and Eyles, 1995; Buggisch et al., 2008).

\section{Conclusion}

We investigate fluid flow in ductile shear zones of the southern Armorican domain through muscovite hydrogen isotope ratios $\left(\delta \mathrm{D}_{\mathrm{Ms}}\right)$ from syntectonic leucogranites emplaced within detachment footwalls and strike-slip fault systems. Mica fish from the lower part of detachment footwalls reveal a typical metamorphic and/or magmatic fluid source, whereas the top of detachment footwalls reveal low $\delta \mathrm{D}_{\mathrm{Ms}}$ values indicative of meteoric fluids infiltration. Syntectonic leucogranites from the SASZ also interacted with surface-derived fluids, but varying degrees of mixing between deep-sourced and surface-derived fluids resulted in intermediate $\delta \mathrm{D}_{\mathrm{Ms}}$ values. Penetration of surface-derived fluids in the crust occurred between $\sim 320$ and 300 Ma by the means of upper-crustal brittle fracture networks while active shear zones continuously exhumed lower-crustal rocks. Ancient rainfall $\delta \mathrm{D}$ values are relatively high compared to present-day major orogens and can be explained by moderate paleoelevation and/or warm paleoclimatic and equatorial paleogeographic 
conditions. Variscan shear zones in the Armorican Massif represented major orogen-scale structures where fluids from both the Earth's surface and the deep parts of the crust mixed.

\section{Acknowledgements}

$\mathrm{CD}$ and $\mathrm{AG}$ acknowledge a $\mathrm{PhD}$ studentship from the University of Plymouth. The authors are grateful to R. Tartèse and $\mathrm{C}$. Ballouard for providing samples from their studies, to $\mathrm{J}$. Fiebig for laboratory support and L. Jolivet for constructive comments on an earlier version of the manuscript. We thank the editors Georges Calas and Anne Borcherds, as well as Catriona Menzies and one anonymous reviewer for fruitful discussions that greatly improved the manuscript.

\section{References}

Ballèvre, M., Bosse, V., Dabard, M., Fourcade, S., Paquette, J., Peucat, J., and Pitra, P., 2013, Histoire géologique du Massif armoricain : actualité de la recherche: Bull. Soc. géol. minéral. Bretagne, v. 10-11, no. D, p. 5-96.

Ballouard, C., Boulvais, P., Poujol, M., Gapais, D., Yamato, P., Tartèse, R., and Cuney, M., 2015, Tectonic record, magmatic history and hydrothermal alteration in the Hercynian Guérande leucogranite, Armorican Massif, France: LITHOS, v. 220-223, p. 1-22, doi: 10.1016/j.lithos.2015.01.027.

Ballouard, C., Poujol, M., Boulvais, P., Branquet, Y., Tart??se, R., Vigneresse, J.L., Tartèse, R., and Vigneresse, J.L., 2016, Nb-Ta fractionation in peraluminous granites: A marker of the magmatic-hydrothermal transition: Geology, v. 44, no. 3, p. 231-234, doi:

$10.1130 / \mathrm{G} 37475.1$

Ballouard, C., Poujol, M., Boulvais, P., Mercadier, J., Tartèse, R., Venneman, T., Deloule, E., Jolivet, M., Kéré, I., Cathelineau, M., and Cuney, M., 2017, Magmatic and hydrothermal behavior of uranium in syntectonic leucogranites: The uranium mineralization associated with the Hercynian Guérande granite (Armorican Massif, France): Ore Geology Reviews, v. 80, no. July, p. 309-331, doi: 10.1016/j.oregeorev.2016.06.034.

Ballouard, C., Poujol, M., Mercadier, J., Deloule, E., Boulvais, P., Baele, J.M., Cuney, M., and Cathelineau, M., 2018, Uranium metallogenesis of the peraluminous leucogranite from the Pontivy-Rostrenen magmatic complex (French Armorican Variscan belt): the result of long-term oxidized hydrothermal alteration during strike-slip deformation: Mineralium Deposita, v. 53, no. 5, p. 601-628, doi: 10.1007/s00126-017-0761-5. 
Boiron, M.C., Cathelineau, M., Banks, D.A., Fourcade, S., and Vallance, J., 2003, Mixing of metamorphic and surficial fluids during the uplift of the Hercynian upper crust:

Consequences for gold deposition: Chemical Geology, v. 194, no. 1-3, p. 119-141, doi: 10.1016/S0009-2541(02)00274-7.

Bosse, V., Ballèvre, M., and Vidal, O., 2002, Ductile thrusting recorded by the garnet isograd from blueschist-facies metapelites of the Ile de Groix, Armorican Massif, France: Journal of Petrology, v. 43, no. 3, p. 485-510, doi: 10.1093/petrology/43.3.485.

Boucot, A.J., Xu, C., Scotese, C.R., and Morley, R.J., 2013, Phanerozoic Paleoclimate: An Atlas of Lithologic Indicators of Climate: SEPM (Society for Sedimentary Geology), Tulsa, Oklahoma, U.S.A.

Brown, M., and Dallmeyer, R.D.R., 1996, Rapid Variscan exhumation and the role of magma in core complex formation: southern Brittany metamorphic belt, France: Journal of Metamorphic Geology, v. 14, no. 3, p. 361-379, doi: 10.1111/j.1525-1314.1996.00361.x. Buggisch, W., Joachimski, M.M., Sevastopulo, G., and Morrow, J.R., 2008, Mississippian $\delta^{13} \mathrm{C}_{\text {carb }}$ and conodont apatite $\delta^{18} \mathrm{O}$ records - Their relation to the Late Palaeozoic Glaciation: Palaeogeography, Palaeoclimatology, Palaeoecology, v. 268, no. 3-4, p. 273-292, doi: 10.1016/j.palaeo.2008.03.043.

Bukovská, Z., Jeřábek, P., and Morales, L.F.G., 2016, Major softening at brittle-ductile transition due to interplay between chemical and deformation processes: An insight from evolution of shear bands in the South Armorican Shear Zone: Journal of Geophysical Research: Solid Earth, v. 121, no. 2, p. 1158-1182, doi: 10.1002/2015JB012319. Campani, M., Mulch, A., Kempf, O., Schlunegger, F., and Mancktelow, N., 2012, Miocene paleotopography of the Central Alps: Earth and Planetary Science Letters, v. 337-338, p. 174-185, doi: 10.1016/j.eps1.2012.05.017.

Field, C.W., and Fifarek, R.H., 1985, Light stable-isotope systematics in the epithermal environment, in Berger, B.R. and Bethke, P.M. eds., Geology and Geochemistry of Epithermal Systems, Soc. of Econ. Geol., Boulder, Colorado, Colorado, p. 99-128. Fricke, H.C., Wickham, S.M., and O'Neil, J.R., 1992, Oxygen and hydrogen isotope evidence for meteoric water infiltration during mylonitization and uplift in the Ruby Mountains-East Humboldt Range core complex, Nevada: Contributions to Mineralogy and Petrology, v. 111, no. 2, p. 203-221, doi: 10.1007/BF00348952.

Gapais, D., 1989, Shear structures within deformed granites: mechanical and thermal indicators: Geology, v. 17, no. 12, p. 1144-1147, doi: 10.1130/00917613(1989)017<1144:SSWDGM>2.3.CO.

This article is protected by copyright. All rights reserved. 
Gapais, D., and Boundi, A.L.B., 2014, Pegmatite mylonites: origin and significance:

Geological Society, London, Special Publications, v. 409, p. SP409.7, doi: 10.1144/SP409.7.

Gapais, D., Brun, J.-P., Gumiaux, C., Cagnard, F., Ruffet, G., and Le Carlier De Veslud, C., 2015, Extensional tectonics in the Hercynian Armorican belt (France). An overview: Bulletin de la Société Géologique de France, v. 186, no. 2-3, p. 117-129, doi:

10.2113/gssgfbull.186.2-3.117.

Gébelin, A., Jessup, M.J., Teyssier, C., Cosca, M.A., Law, R.D., Brunel, M., and Mulch, A., 2017, Infiltration of meteoric water in the South Tibetan Detachment (Mount Everest,

Himalaya): When and why? Tectonics, v. 36, no. 4, p. 690-713, doi:

10.1002/2016TC004399.

Gébelin, A., Mulch, A., Teyssier, C., Heizler, M., Vennemann, T., and Seaton, N.C.A., 2011, Oligo-Miocene extensional tectonics and fluid flow across the Northern Snake Range detachment system, Nevada: Tectonics, v. 30, no. 5, doi: 10.1029/2010TC002797.

Gébelin, A., Mulch, A., Teyssier, C., Jessup, M.J., Law, R.D., and Brunel, M., 2013, The Miocene elevation of Mount Everest: Geology, v. 41, no. 7, p. 799-802, doi: 10.1130/G34331.1.

Gébelin, A., Mulch, A., Teyssier, C., Page Chamberlain, C., and Heizler, M., 2012, Coupled basin-detachment systems as paleoaltimetry archives of the western North American Cordillera: Earth and Planetary Science Letters, v. 335-336, p. 36-47, doi: 10.1016/j.epsl.2012.04.029.

Gébelin, A., Teyssier, C., Heizler, M.T., and Mulch, A., 2015, Meteoric water circulation in a rolling-hinge detachment system (northern snake range core complex, Nevada): Bulletin of the Geological Society of America, v. 127, no. 1-2, p. 149-161, doi: 10.1130/B31063.1.

González-Bonorino, G., and Eyles, N., 1995, Inverse relation between ice extent and the late Paleozoic glacial record of Gondwana: Geology, v. 23, no. 11, p. 1015, doi: 10.1130/00917613(1995)023<1015:IRBIEA >2.3.CO;2.

ten Grotenhuis, S.M., Trouw, R.A.J., and Passchier, C.W., 2003, Evolution of mica fish in mylonitic rocks: Tectonophysics, v. 372, no. 1-2, p. 1-21, doi: 10.1016/S00401951(03)00231-2.

Guggenheim, S., Chang, Y.H., and Koster Van Groos, A.F., 1987, Muscovite dehydroxylation: high-temperature studies.: American Mineralogist, v. 72, no. 5-6, p. 537550 .

Le Hébel, F., Fourcade, S., Boiron, M.C., Cathelineau, M., Capdevila, R., and Gapais, D., 2007, Fluid history during deep burial and exhumation of oil-bearing volcanics, Hercynian 
Belt of southern Brittany, France: American Journal of Science, v. 307, no. 9, p. 1096-1125, doi: $10.2475 / 09.2007 .03$.

Le Hébel, F., Vidal, O., Kienast, J., and Gapais, D., 2002, Les « Porphyroïdes » de Bretagne méridionale : une unité de HP-BT dans la chaîne hercynienne: Comptes Rendus Geoscience, v. 334, no. 3, p. 205-211, doi: 10.1016/S1631-0713(02)01746-7.

Jegouzo, P., 1980, The South Armorican Shear Zone: Journal of Structural Geology, v. 2, no. 1, p. 39-57.

Jenkin, G.R.T., Craw, D., and Fallick, A.E., 1994, Stable isotopic and fluid inclusion evidence for meteoric fluid penetration into an active mountain belt; Alpine Schist, New Zealand: Journal of Metamorphic Geology, v. 12, no. 4, p. 429-444, doi: 10.1111/j.15251314.1994.tb00033.x.

Jones, K.A., and Brown, M., 1990, High-temperature 'clockwise' P-T paths and melting in the development of regional migmatites: an example from southern Brittany, France: Journal of Metamorphic Geology, v. 8, p. 551-578.

Langille, J.M., Jessup, M.J., Cottle, J.M., Newell, D., and Seward, G., 2010, Kinematic evolution of the Ama Drime detachment: Insights into orogen-parallel extension and exhumation of the Ama Drime Massif, Tibet-Nepal: Journal of Structural Geology, v. 32, no. 7, p. 900-919, doi: 10.1016/j.jsg.2010.04.005.

Lemarchand, J., Boulvais, P., Gaboriau, M., Boiron, M.-C., Tartese, R., Cokkinos, M., Bonnet, S., and Jegouzo, P., 2012, Giant quartz vein formation and high-elevation meteoric fluid infiltration into the South Armorican Shear Zone: geological, fluid inclusion and stable isotope evidence: Journal of the Geological Society, v. 169, no. 1, p. 17-27, doi:

10.1144/0016-76492010-186.

Losh, S., 1997, Stable isotope and modeling studies of fluid-rock interaction associated with the Snake Range and Mormon Peak detachment faults, Nevada: Geological Society of America Bulletin, v. 109, no. 3, p. 300-323, doi: 10.1130/00167606(1997)109<0300:SIAMSO>2.3.CO;2.

Mariani, E., Brodie, K.H., and Rutter, E.H., 2006, Experimental deformation of muscovite shear zones at high temperatures under hydrothermal conditions and the strength of phyllosilicate-bearing faults in nature: Journal of Structural Geology, v. 28, no. 9, p. 15691587, doi: 10.1016/j.jsg.2006.06.009.

McCaig, A.M., 1988, Deep fluid circulation in fault zones: Geology, v. 16, no. 10, p. 867, doi: 10.1130/0091-7613(1988)016<0867:DFCIFZ>2.3.CO;2.

This article is protected by copyright. All rights reserved. 
Turrillot, P., Augier, R., Monié, P., Faure, M., Monié, P., and Faure, M., 2011a, Late orogenic exhumation of the Variscan high-grade units (South Armorican Domain, western France), combined structural and ${ }^{40} \mathrm{Ar} /{ }^{39} \mathrm{Ar}$ constraints: Tectonics, v. 30 (TC5007, p. 1-27, doi: 10.1029/2010TC002788.

Turrillot, P., Faure, M., Martelet, G., Chen, Y., and Augier, R., 2011b, Pluton-dyke relationships in a Variscan granitic complex from AMS and gravity modelling. Inception of the extensional tectonics in the South Armorican Domain France): Journal of Structural Geology, v. 33, no. 11, p. 1681-1698, doi: 10.1016/j.jsg.2011.08.004.

Upton, P., Koons, P.O., and Chamberlain, C.P., 1995, Penetration of deformation-driven meteoric water into ductile rocks: Isotopic and model observations from the Southern Alps, New Zealand: New Zealand Journal of Geology and Geophysics, v. 38, no. 4, p. 535-543, doi: 10.1080/00288306.1995.9514680.

\section{Figure captions}

Figure 1. General map of the southern Armorican domain and E-W cross-section (AA'). Samples sites colours indicate the calculated hydrogen isotope composition of fluids that interacted with muscovite in syntectonic granites. E.Q: Elliant quarry; Q.G.: Questembert granite; L.: Lizio leucogranite; S.: Sarzeau leucogranite; Q.: Quiberon leucogranite G.: Guérande leucogranite; modified after Gapais et al. (1993).

Figure 2. Representative quartz microstructure from the SASZ and detachment zones as well

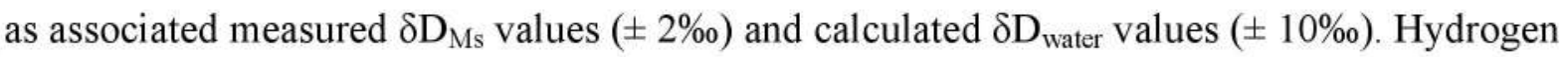
isotope ratios of water have been calculated from $\delta \mathrm{D}_{\mathrm{Ms}}$ values using a deformation temperature of $550 \pm 100^{\circ} \mathrm{C}$ and temperature-dependent fractionation equations from Suzuoki and Epstein (1976).

Figure 3. 3D simplified sketch showing the crustal-scale ductile shear zones and associated $\delta \mathrm{D}_{\text {water }}$ values. Blue arrows: meteoric fluids infiltration. Red Arrows: deep crustal fluids. SASZ: South Armorican Shear Zone.

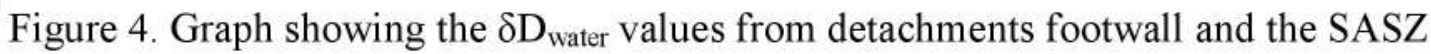
calculated from measured $\delta \mathrm{D}$ values of synkinematic muscovite (this study). Note the progressive involvement of meteoric fluids from an unmixed deep crustal end-member fluid in the Sarzeau lower part of detachment footwall $\left(\delta D_{\text {water }}\right.$ value $\left.=-33 \%\right)$ to greater mixing with meteoric fluids in the Piriac and Quiberon upper part of detachment footwalls $\left(\delta \mathrm{D}_{\text {water }}\right.$ value $=-74 \%$ o). $M F / R$ : meteoric fluid/rock ratio.

This article is protected by copyright. All rights reserved. 


\section{Supporting Information}

Additional Supporting Information may be found in the online version of this article:

Figure S1. Muscovite microstructures in Quiberon and Piriac

Figure S2. Muscovite microstructures in Sarzeau and the SASZ

Text S1. Methods

Table S1. GPS localization and hydrogen isotope composition of muscovite $\left(\delta \mathrm{D}_{\mathrm{Ms}}\right)$

Table S2. Calculated $\delta D_{\text {water }}$ values with uncertainties

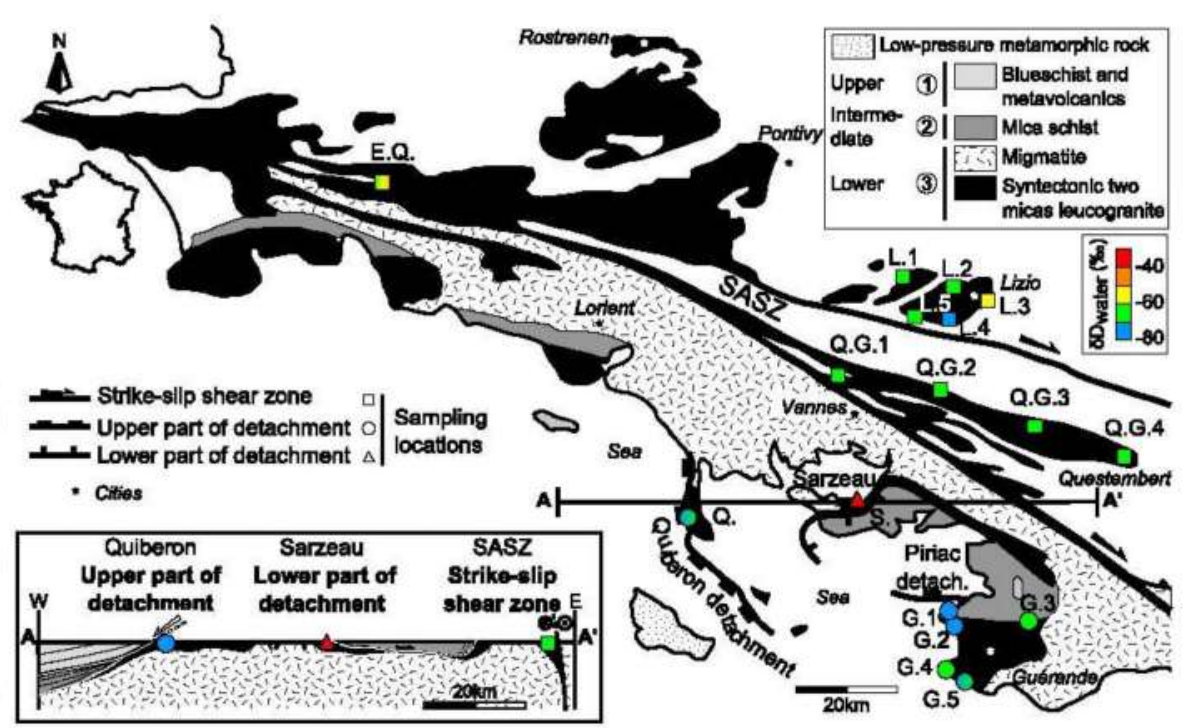

This article is protected by copyright. All rights reserved. 

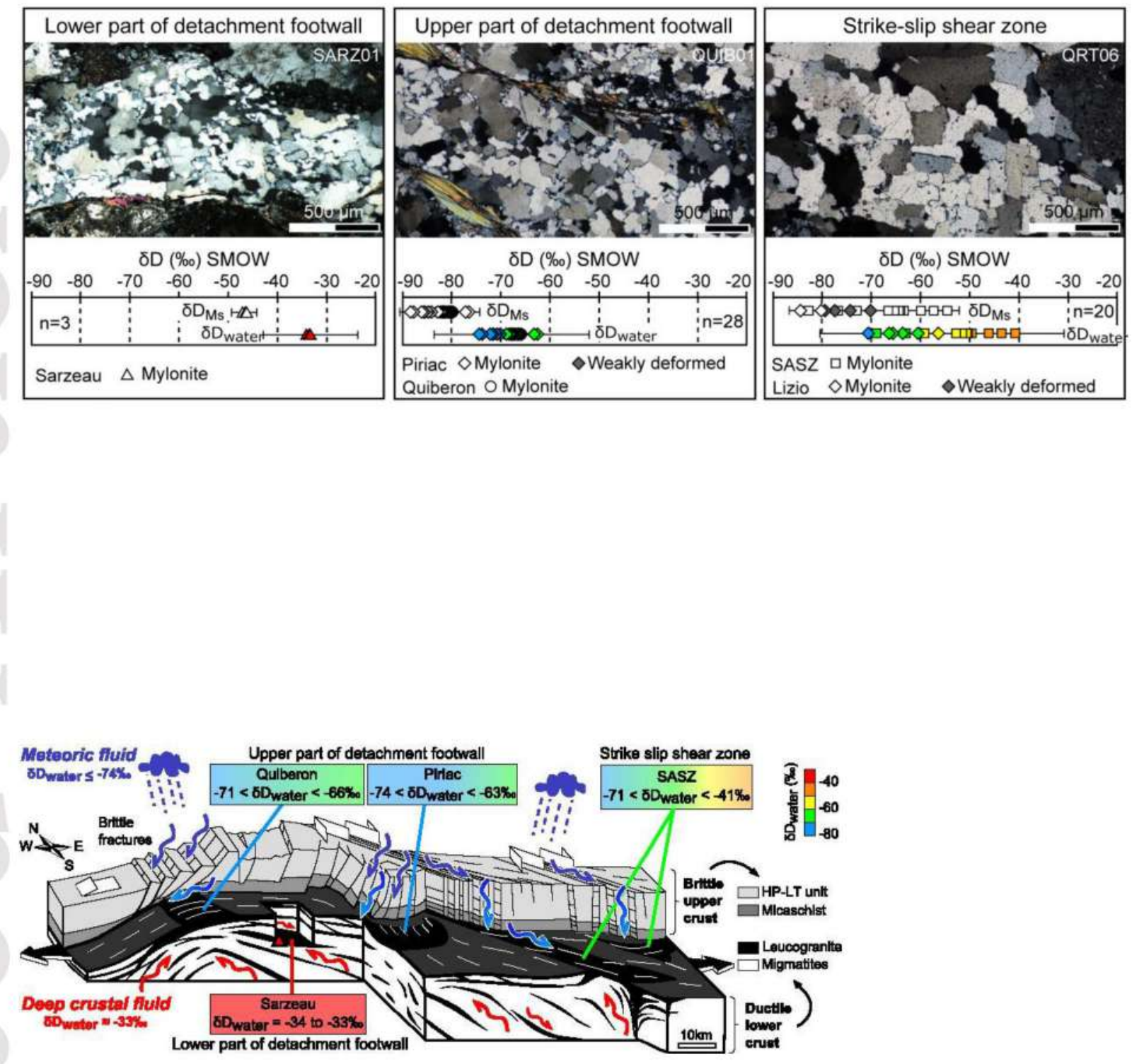

This article is protected by copyright. All rights reserved. 


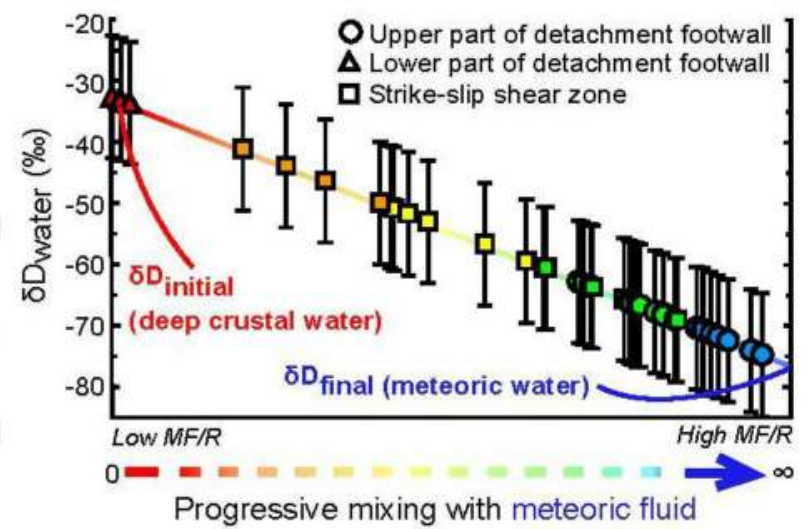

This article is protected by copyright. All rights reserved. 